\title{
Critical swimming speed of the southern straight-mouth nase Pseudochondrostoma willkommii (Steindachner, 1866), a potamodromous cyprinid from southern Europe
}

\author{
C. M. Alexandre ${ }^{1, *}$, R. Branca ${ }^{1}$, B. R. Quintella ${ }^{1,2}$ and P. R. Almeida ${ }^{1,3}$ \\ ${ }^{1}$ MARE-Centro de Ciências do Mar e do Ambiente, Universidade de Évora, Largo dos Colegiais 2, 7004-516, \\ Évora, Portugal. \\ 2 Departamento de Biologia Animal, Faculdade de Ciências da Universidade de Lisboa, Campo Grande, \\ 1749-016, Lisboa, Portugal. \\ ${ }^{3}$ Departamento de Biologia, Escola de Ciências e Tecnologia, Universidade de Évora, Largo dos Colegiais 2, \\ 7004-516, Évora, Portugal. \\ * Corresponding author: cmalexandre@fc.ul.pt
}

Received: 19/01/2016

Accepted: 06/07/2016

\begin{abstract}
Critical swimming speed of the southern straight-mouth nase Pseudochondrostoma willkommii (Steindachner, 1866), a potamodromous cyprinid from southern Europe

Critical swimming speed $\left(U_{\text {crit }}\right)$ of the potamodromous southern straight-mouth nase was assessed in a modified Blazka-type swim tunnel. Forty-one $P$. willkommii were tested and exhibited a mean $\pm \mathrm{SD} U_{\text {crit }}$ of $0.54 \pm 0.07 \mathrm{~m} / \mathrm{s}$. The sex of experimental fish had no effect on $U_{\text {crit }}$ but a significant positive relationship was found between swimming performance and the body condition of tested fish. Results from this study can be used to improve the current design of fish passes targeting this, or similar, potamodromous fish species.
\end{abstract}

Key words: Southern straight-mouth nase, critical swimming speed, cyprinids, Mediterranean rivers.

\section{RESUMO}

Velocidade critica de natação da boga do Guadiana Pseudochondrostoma willkommii (Steindachner, 1866), um ciprinídeo potamódromo do Sul da Europa

A velocidade critica de natação $\left(U_{\text {crit }}\right)$ da boga do Guadiana, uma espécie potamódroma, foi determinada com recurso a um túnel de natação do tipo Blazka. No total, quarenta e uma bogas foram testadas, tendo demonstrado uma $U_{\text {crit }}$ média \pm S.D. de $0.54 \pm 0.07 \mathrm{~m} / \mathrm{s}$. O sexo dos peixes não teve efeito nos valores de $U_{\text {crit }}$ observados, mas foi encontrada uma relação positiva e significativa entre a capacidade natatória dos individuos desta espécie e a respetiva condição corporal. Os resultados deste trabalho podem contribuir para a melhoria do desenho e configuração de passagens para peixes dedicadas a este tipo de espécies potamódromas.

Palavras-chave: Boga do Guadiana, velocidade critica de natação, ciprinídeos, ríos mediterrânicos.

\section{INTRODUCTION}

Swimming capacity is one of the most important bio-ecological features determining survival of fish species and influencing their ability to gather available food resources, reproduce or avoid unfavourable environmental conditions (Plaut, 2001). The swimming performance of fish can 
be measured using different methods (Hammer, 1995), but the most common way to determine this biological feature in the laboratory is to test their critical swimming speed $\left(U_{\text {crit }}\right)$. This parameter is related to the category of prolonged swimming and was first used by Brett (1964) to designate the maximum velocity a fish could maintain for a precise time period (Beamish, 1978). Critical swimming speed is considered to be a relatively close measure of the maximum aerobic capacity of the fish, while it also includes aerobic and anaerobic swimming (Hammer, 1995). Most of the studies on the evaluation of swimming performance of fish species are focused on salmonids due to their commercial and recreational value (e.g., Peake et al., 1997; Peake, 2008), and suitable information on the swimming capacity of Mediterranean fishes, especially Iberian cyprinids, remains relatively scarce. The Iberian fluvial network is complex, comprising a high number of independent river basins where the different species and populations are strongly isolated and highly vulnerable to habitat modifications (Collares-Pereira et al., 2000; Clavero et al., 2004). Considering the increasing degree of anthropogenic alteration in Iberian fluvial ecosystems, information about the swimming abilities of fish from this region is extremely important for predicting the ecological consequences of man-made habitat fragmentation and enhancing respective mitigation measures (e.g. fish pass construction). This is particularly important for species that migrate, like potamodromous fishes, moving considerable distances along the river to spawn. Studies about the swimming performance of Iberian cyprinids have already been conducted in recent years, using swim tunnels or open-channel flumes (Mateus et al., 2008; Romão et al., 2012; Alexandre et al., 2014; Sanz-Ronda et al., 2015), but broader information is required to increase taxonomic and geographic representativeness and applicability of the obtained results, especially for species inhabiting southern temporary rivers, whose specific adaptations to a particular hydrologic regime can constrain the application of general rehabilitation measures (Gasith \& Resh, 1999). Therefore, in this study we aimed to determine the critical swimming speed of the southern straight-mouth nase Pseudochondrostoma willkommii (Steindachner, 1866), a potamodromous cyprinid, listed as Vulnerable in the Portuguese Red List of Threatened Vertebrates (Cabral et al., 2005). This species is endemic to southern Iberian rivers, characterized by a variable hydrologic regime with harsh environmental conditions, especially during the summer period.

\section{MATERIAL AND METHODS}

\section{Fish capture}

Experimental animals were captured in the $\mathrm{Ri}$ ver Chança, a tributary of the River Guadiana, located in the south of Portugal (WGS84$\left.37^{\circ} 42^{\prime} 54.25^{\prime \prime} \mathrm{N} ; 7^{\circ} 26^{\prime} 12.90^{\prime \prime} \mathrm{W}\right)$, using electrofishing gear (Hans Grassl EL 62 generator, DC, 300 V, Schönau am Königssee, Germany). Fish were captured during February 2014, which is described in the literature as the beginning of the reproductive season of the target species (Herrera \& Fernandez-Delgado, 1994). To prevent the existence of size effects in the tested individuals and avoid the use of a relative measure of swimming performance, selected nases were all of the same length class, i.e., 150-200 mm. After capture, a total of 41 southern straight-mouth nases (30 males and 11 females) were immediately brought to the laboratory and placed in an indoor (2000 L) circular holding tank with controlled photoperiod ( $12 \mathrm{~h}$ light/12 h dark) and a proper life support system to maintain water quality (controlled ammonia, oxygen levels and temperature).

\section{Experimental procedure}

This study was conducted in accordance with all the Portuguese legislation regarding animal capture, manipulation and experimentation for scientific purposes, including individual licences for accredited researchers Pedro R. Almeida and Bernardo R. Quintella, issued by the Portuguese National Authority for Animal Health (DGAVDireção Geral de Alimentação e Veterinária), and 
in accordance with the guidelines of the Federation of European Laboratory Animal Science Associations (FELASA).

After capture, fish were allowed to recover for at least 2 days prior to the swimming performance tests and were not fed during the entire experimental period ( $<2$ weeks). Each fish was tested only once. Critical swimming speed tests of captured $P$. willkommii were conducted following the experimental procedure defined by Brett (1964) using swim tunnel apparatus. The swim tunnel was designed as a recirculating water tunnel incorporating a $72 \mathrm{~cm}$ long and $25 \mathrm{~cm}$ diameter clear acrylic tube with metal grids at both ends used as the swim chamber. A $2.3 \mathrm{hp}$ submersible propeller motor (Model SR4620.410 HG; Flyght, Gesallvagen, Sweden) pumped water through the system, allowing a steady current velocity range between 0 and $1.5 \mathrm{~m} / \mathrm{s}$ in the swim chamber, fully controlled by the operator. For a more detailed description of the swim tunnel components and operation please see Mateus et al. (2008). Temperature was kept constant $\left(16^{\circ} \mathrm{C}\right)$ during the entire study period, both in the holding tank and in the swim apparatus. The temperature level experienced by the fish during the entire procedure was set to be within the range to which this species is subjected in the wild during the spawning season (i.e., February-April) (Herrera \& Fernandez-Delgado, 1994). Before the tests, fish underwent a $1 \mathrm{~h}$ acclimation period at a low water velocity of $0.20 \mathrm{~m} / \mathrm{s}$ to recover from handling and allow the fish to orient in the swim chamber. Following the conditioning period, the water velocity was increased by $0.15 \mathrm{~m} / \mathrm{s}$ every 30 min until exhaustion was reached. Fish were discouraged from resting on the rear grid using an electric field (7-12 V, $4 \mathrm{~A})$ that was turned on for $2 \mathrm{~s}$ when the fish appeared to be touching the grid. This was enough to cause complete avoidance of the grid and to encourage fish to swim forwards. Exhaustion was considered to have been reached at the point at which a fish was unable to move away from the grid despite consecutive $2 \mathrm{~s}$ electric stimulations in a maximum $10 \mathrm{~s}$ period (Brett, 1964; Mateus et al., 2008). At this stage, the test ended and absolute $U_{\text {crit }}$ $(\mathrm{m} / \mathrm{s})$ was calculated using the formula described by Brett (1964): $U_{\text {crit }}=U_{i}+\left[U_{i i} \times\left(T_{i} \times T_{i i}^{-1}\right)\right]$, where $U_{i}$ is the highest velocity maintained for the entire $30 \mathrm{~min}$ interval $(\mathrm{m} / \mathrm{s}), U_{i i}$ is the velocity increment $(\mathrm{m} / \mathrm{s}), T_{i}$ is the time elapsed at exhaustion velocity (s) and $T_{i i}$ is the prescribed interval time (s). The velocity at which fish were swimming in the swim chamber was corrected for the solid blocking effect, using the expression developed by Bell and Terhune (1970). At the end of trials, fish were euthanized by immersion in an overdose of 2-phenoxyethanol ( $1 \mathrm{ml} / \mathrm{L})$ and measured for cross-sectional area, total length $\left(L_{t}, \pm\right.$ $1 \mathrm{~mm})$, total weight $\left(W_{t}, \pm 0.01 \mathrm{~g}\right)$ and gonad weight $\left(W_{g}, \pm 0.01 \mathrm{~g}\right)$. The sex of each nase was macroscopically identified.

\section{Data analysis}

Biometric data (Table 1) was used to determine the gonadossomatic index $\left[I_{g}=\left(W_{g} \times W_{t}^{-1}\right) \times 100\right]$ and Fulton's condition factor $\left[K^{\prime}=\left(W_{t} \times L_{t}^{-3}\right) \times\right.$ 100] for each tested individual. Before applying the statistical analyses conducted in this study, all assumptions for the use of appropriate parametric methodologies were tested, and in the case of non-fulfilment even after suitable data transformation, the equivalent nonparametric analysis was employed. A Mann-Whitney test $(U)$ was conducted to test for differences in $U_{\text {crit }}$ between male and female nases. Regression analyses were

Table 1. Data (mean [range]) of successfully tested male and female southern straight-mouth nases: total length $\left(L_{t}\right.$, mm); total weight $\left(W_{t}, \mathrm{~g}\right)$; gonadossomatic index $\left(I_{g}\right)$, Fulton's condition factor $\left(K^{\prime}\right)$, critical swimming speed $\left(U_{\text {crit }}, \mathrm{m} / \mathrm{s}\right)$. Dados $(m e ́ d i a$ [intervalo]) dos machos e fêmeas de boga do Guadiana testados com êxito: comprimento total ( $\mathrm{L}_{\mathrm{t}}$, mm); peso total ( $\left.\mathrm{W}_{\mathrm{t}}, \mathrm{g}\right) ;$ indice gonadossomático $\left(\mathrm{I}_{\mathrm{g}}\right)$, Coeficiente de Condição Corporal de Fulton $\left(\mathrm{K}^{\prime}\right)$; velocidade critica de natação $\left(\mathrm{U}_{\text {crit }}\right.$, m/s).

\begin{tabular}{lccccc}
\hline & $L_{t}(\mathrm{~mm})$ & $W_{t}(\mathrm{~g})$ & $I_{g}$ & $K^{\prime}$ & $U_{\text {crit }}(\mathrm{m} / \mathrm{s})$ \\
\hline Males $(\mathrm{n}=21)$ & $16.35[15.10-18.90]$ & $31.18[22.24-49.73]$ & $5.75[3.96-7.36]$ & $0.70[0.63-0.79]$ & $0.54[0.39-0.67]$ \\
Females $(\mathrm{n}=8)$ & $17.13[15.30-19.20]$ & $37.18[24.99-55.89]$ & $9.91[5.69-17.43]$ & $0.72[0.61-0.79]$ & $0.54[0.35-0.66]$ \\
\hline
\end{tabular}


conducted to confirm the absence of fish length and gonad development level (gonadossomatic index, $I_{g}$ ) effects (even within the low range of size class and the short time span considered in the study) in the obtained results and, at the same time, test the relationship between the Fulton's condition factor, $K^{\prime}$, and determined $U_{\text {crit }}$ values. All statistical analyses were conducted using STATISTICA 12.6 (StatSoft).

\section{RESULTS}

From a total of 41 fish, 29 (70.3\%, 21 males and 8 females) successfully completed the $U_{\text {crit }}$ test. Fish (8 males and 4 females) with poor rheophilic behaviour (i.e., moving backwards and forwards in the swim chamber) during the acclimation period and initial increments of the swimming test were removed from further analysis.

The average $U_{\text {crit }}$ observed for the tested fish was $0.54 \pm 0.07 \mathrm{~m} / \mathrm{s}$ (mean $\pm \mathrm{SD})$. No sex-related differences in $U_{\text {crit }}$ were observed (Mann-Whitney $U=82.00 ; P$-value $>0.05$ ) between male
$(0.54 \pm 0.07 \mathrm{~m} / \mathrm{s})$ and female $(0.54 \pm 0.06 \mathrm{~m} / \mathrm{s})$ nases (Fig. 1). Linear regression analyses revealed that fish length and gonad development level were not significantly related with $U_{\text {crit }}$ values $(P$-value $>0.05)$, confirming the absence of size and gonad maturity biases in the obtained results. On the other hand, a significant positive linear relationship was found between $U_{\text {crit }}$ and $K^{\prime}$ condition $\left(y=0.70 x+0.04 ; R^{2}=0.19\right.$; d.f. $=1,26 ; P$-value $<0.01)$, indicating that nases with higher body condition had, in general, higher $U_{\text {crit }}$ values (Fig. 2).

\section{DISCUSSION}

This study provided important insights about some components of the swimming performance of a migratory freshwater fish species from the Iberian Peninsula, the southern straight-mouth nase, which, until this date, were completely unknown. This type of information will help responsible entities with the suitable integration of this potamodromous species within manage-

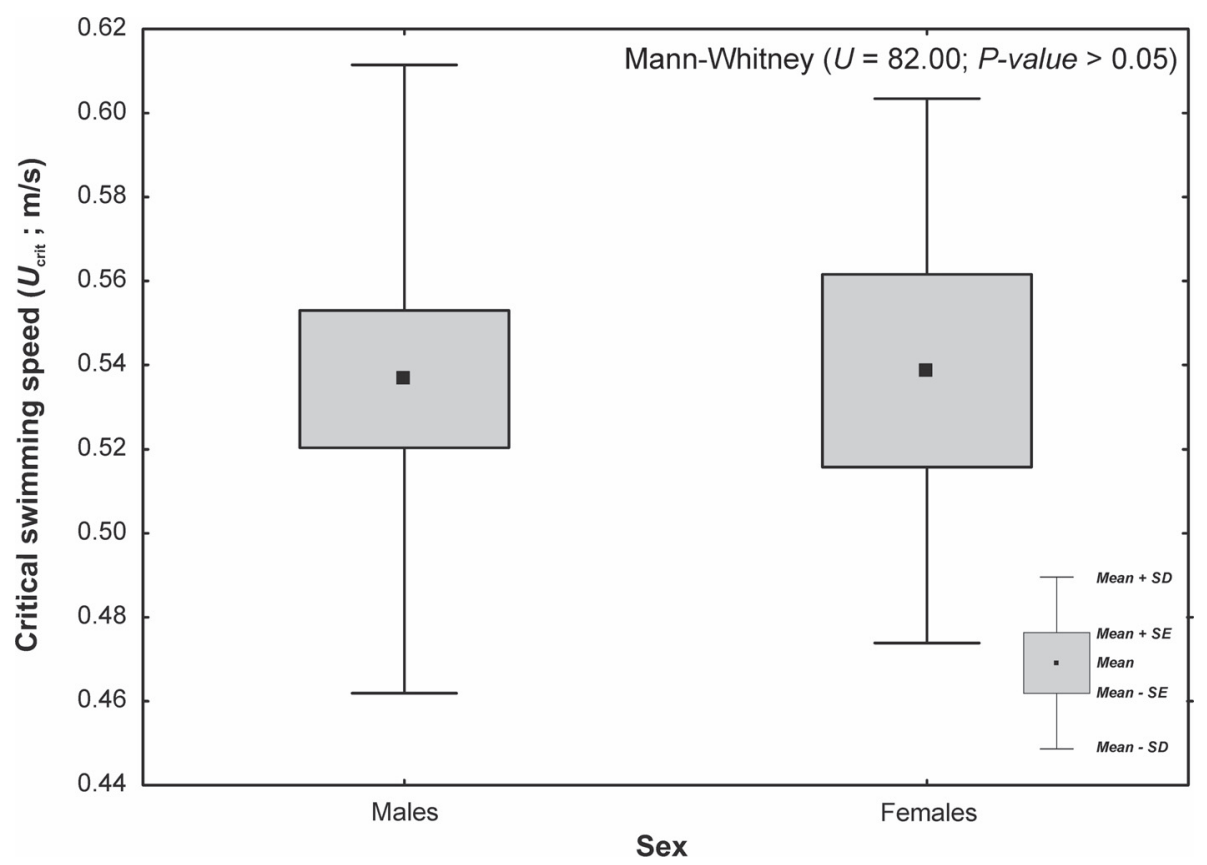

Figure 1. Box-plots showing distribution of the critical swimming speeds $\left(U_{\text {crit }}, \mathrm{m} / \mathrm{s}\right)$ obtained for male and female southern straight-mouth nases. Box-plots representativos da distribuição dos valores de velocidade critica de natação $\left(\mathrm{U}_{\text {crit }}\right.$, m/s) obtidos para machos e fêmeas de boga do Guadiana. 
ment programs aiming to restore or improve longitudinal connectivity in fragmented watercourses, particularly in the southern regions of the Peninsula.

Critical swimming speeds observed in this study for the southern straight-mouth nase were considerably lower than the average $U_{\text {crit }}$ values $(0.81 \mathrm{~m} / \mathrm{s}, 0.70-0.75 \mathrm{~m} / \mathrm{s}$ if considering a similar 150-200 mm size class) described for the Iberian barbel Luciobarbus bocagei (Steindachner, 1864) (Mateus et al., 2008), another potamodromous cyprinid species from this region. In comparison with the $U_{\text {crit }}$ values achieved by the northern Iberian chub Squalius carolitertii (Doadrio, 1988) (Romão et al., 2012), a resident species from northern river basins with permanent flow, theoretically with less locomotor capacity (Romão et al., 2012), the southern nase presented similar overall average $U_{\text {crit }}$ values $(0.54 \mathrm{~m} / \mathrm{s})$, but a lower swimming capability when the comparison was made with chubs from the same size class
(150-200 mm; 0.57-0.70 m/s). Higher average $U_{\text {crit }}$ values than those observed in the present study for the target species were also described by Romão et al. (2012) for a congener species, the Iberian straight-mouth nase Pseudochondrostoma polylepis (Steindachner, 1864) $(0.78 \mathrm{~m} / \mathrm{s})$, although the latter focused on a wider range of size classes, including larger fish with higher swimming capacities and smaller fish with lower performances. Considering only nases from the same size class as the ones tested in the present study (150-200 mm), $U_{\text {crit }}$ values of $P$. polylepis were still higher $(0.69-0.76 \mathrm{~m} / \mathrm{s})$ than the average value described for $P$. willkommii, implying that the latter species does indeed have lower swimming capability than its congener. The swimming performance of freshwater fishes can be influenced by a number of biotic and abiotic variables, but the relationship between habitat conditions and swimming performance has recently gathered a lot of attention (e.g., Lan-

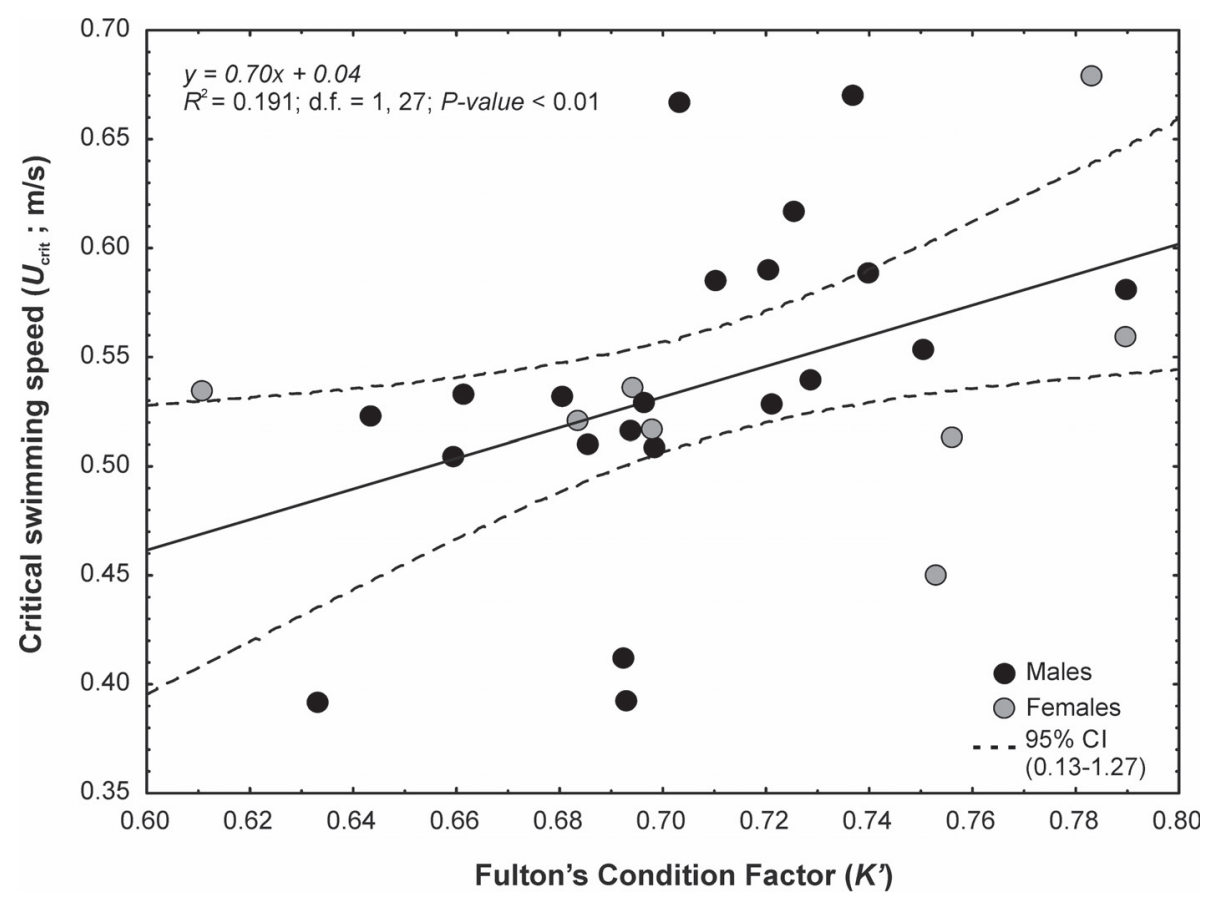

Figure 2. Relationship between Fulton's condition factor $\left(K^{\prime}\right)$ and critical swimming speed $\left(U_{\text {crit }}\right.$, m/s), obtained by a linear regression method (with 95\% confidence intervals), for male and female southern straight-mouth nases (curve fit for both genders by $y=0.70 x+0.04 ; R^{2}=0.19 ;$ d.f. $\left.=1,26 ; P<0.01\right)$. Relação entre o Coeficiente de Condição Corporal de Fulton $\left(\mathrm{K}^{\prime}\right)$ e a velocidade critica de natação $\left(U_{\text {crit }}, \mathrm{m} / \mathrm{s}\right)$, obtida pelo método de regressão linear (intervalos de confiança de $95 \%$ ), para machos e fêmeas de boga do Guadiana (a curva ajusta-se para os dois géneros através da expressão $\mathrm{y}=0.70 \mathrm{x}+0.04 ; \mathrm{R}^{2}=0.19 ; d . f .=1,26 ; \mathrm{P}<0.01$ ). 
gerhans, 2008; Franssen, 2011). P. polylepis is mostly distributed across river basins located in central-northern areas of the Iberian Peninsula, characterized by a lower influence of the Mediterranean climate and higher river gradients associated with a more permanent and intense flow regime. Contrarily, P. willkommii distribution is restricted to southern basins of the Peninsula, characterized by a typical Mediterranean hydrologic regime, in which low gradient rivers have a more variable and temporary flow pattern. Therefore, differences in swimming performance described for both species by this study and that of Romão et al. (2012) may reflect the different habitat conditions, particularly in terms of streamflow regime, faced by each studied species in their specific habitat. In part, these results corroborate what was previously described in a recent study by Alexandre et al. (2014) in which significant $U_{\text {crit }}$, as well as ecomorphologic, differences were described for two $L$. bocagei populations inhabiting river basins with different hydrologic conditions.

This study showed the absence of $U_{\text {crit }}$ differences between male and female southern straight-mouth nases, which is similar to what has been detected for other Iberian cyprinids (Mateus et al., 2008; Romão et al., 2012). Also, a significant positive linear relationship was found between $U_{\text {crit }}$ and $K^{\prime}$ condition, revealing that more robust southern nases are better swimmers. Within specialized literature, contradictory results about the relationship between body condition and swimming performance seem to be common for freshwater fish species. Kolok (1992) found a significant positive relationship between the condition factor and the aerobic performance of largemouth bass Micropterus salmoides (Lacépède, 1802). Romão et al. (2012) found a similar relationship between these two variables for a congener species of the one tested in this study, the Iberian nase. On the other hand, Sanz-Ronda et al. (2015) found an opposite relationship for the third species of the Pseudochondrostoma genus, describing reduced swimming ability for the more robust northern straight-mouth nase Pseudochondrostoma duriense (Coelho, 1985). The swimming per- formance of northern Iberian chub, a freshwater resident species, seems to be unaffected by the condition factor (Romão et al., 2012). Alexandre et al. (2014) described higher body condition as contributing to lower swimming performance of a southern Iberian barbel population, in comparison with a northern population of the same species, with a leaner and more swim-fit phenotype. The relationship between these two variables seems to be highly complex, varying between habitats, species and populations within the same species. However, despite the existent variability and the need for future research in this area, this relationship should be taken into account when the objective is to propose proper restoration and management programmes particularly directed to the conservation of freshwater fish assemblages. Special attention should be paid to fish species inhabiting highly variable and constraining aquatic habitats, such as the southern straight-mouth nase tested in this study, in which fishes are usually subjected to higher seasonal fluctuations in resource availability (Mas-Marti et al., 2010; Alexandre et al., 2015) and, in consequence, show an increased rate of change in energy reserves and respective body condition (Oliva-Paterna et al., 2003).

Knowledge of the swimming performance of freshwater fish species, and its relationship with environmental, morphologic and physiological features, can be used as a tool by environmental managers to predict and potentially prevent ecological consequences of habitat fragmentation on migratory riverine fish, such as the potamodromous southern nase. However, more recent research on fish exercise and physiology tends to question the validity of forced swimming tests, such as the ones used in this study, to assess the performance of fish species and the utility of critical swimming speeds for the definition of hydraulic configurations within structures implemented in riverine obstacles to mitigate respective fragmentation effects (Peake et al., 2008). Some authors state that experiments performed in small swim chambers underestimate fish swimming performance by producing conservative estimates, while the use of open-channel flumes, in which fish volitionally swim against 
high velocities, reveals much greater maximum swimming speeds than those predicted by the use of swim tunnels (e.g., Tudorache et al., 2007; Castro-Santos et al., 2013; Sanz-Ronda et al., 2015). Future research is needed to assess the differences and validity of estimating swimming performance with swim tunnels or open-channel flumes for a wide variety of fish species but, ultimately, the results obtained in this study for the southern straight-mouth nase can be used in the definition of conservative water velocity profiles in fishways and culverts to increase their passage efficiency for the target species and to assess potential impacts of instream flow alterations (Peake et al., 2008; Tudorache et al., 2008).

\section{ACKNOWLEDGMENTS}

The authors would like to thank F. Romão and R. Monteiro for their assistance in the fieldwork with the fish capture and É. Carvalho for help during the swimming trials. This work was financially supported by national funds through the FCT (Foundation for Science and Technology) strategic plan for MARE (Marine and Environmental Sciences Centre) under Project UID/MAR/04292/2013 and through an FCT postdoctoral grant to Carlos M. Alexandre (SFRH/ BPD/108582/2015).

\section{REFERENCES}

ALEXANDRE, C. M., B. R. QUINTELLA, A. F. FERREIRA, F. ROMÃO \& P. R. ALMEIDA. 2014. Swimming performance and ecomorphology of the Iberian barbel Luciobarbus bocagei (Steindachner, 1864) on permanent and temporary rivers. Ecology of Freshwater Fish, 23: 244-258.

ALEXANDRE, C. M., S. SALES, M. T. FERREIRA \& P. R. ALMEIDA. 2015. Food resources and cyprinid diet in permanent and temporary Mediterranean rivers with natural and regulated flow. Ecology of Freshwater Fish, 24: 629-645.

BEAMISH, F. W. H. 1978. Swimming capacity. In Fish Physiology, Vol. VII (HOAR, W. S. \& D. J. RANDALL, Eds), pp. 101-187. New York: Academic Press.
BELL, W. H. \& L. D. B. TERHUNE. 1970. Water tunnel design for fisheries research. Fisheries Research Board of Canada, Technical Report 195: 169.

BRETT, J. R. 1964. The respiratory metabolism and swimming performance of young sockeye salmon. Journal of the Fisheries Research Board of Canada, 21: 1183-1226.

CABRAL, M. J., J. ALMEIDA, P. R. ALMEIDA, T. DELLINGER, N. FERRAND DE ALMEIDA, M. E. OLIVEIRA, J. M. PALMEIRIM, A. I. QUEIROZ, L. ROGADO \& M. SANTOS-REIS (Eds). 2005. Livro Vermelho dos Vertebrados de Portugal. Lisboa: Instituto de Conservação da Natureza.

CASTRO-SANTOS,T., J. SANZ-RONDA \& J. R. LEGAZPI. 2013. Breaking the speed limit -comparative sprinting performance of brook trout ( $\mathrm{Sal}$ velinus fontinalis) and brown trout (Salmo trutta). Canadian Journal of Fisheries and Aquatic Sciences, 70(2): 280-293.

CLAVERO, M., F. B. GARRIDO \& J. PRENDA. 2004. Fish fauna in Iberian Mediterranean river basins: biodiversity, introduced species and damming impacts. Aquatic Conservation: Marine and Freshwater Ecosystems, 14: 575-585.

COLLARES-PEREIRA, M. J., I. G. COWX, F. RIBEIRO, A. RODRIGUES \& L. ROGADO. 2000. Threats imposed by water resource development schemes on the conservation of endangered fish species on the Guadiana River Basin in Portugal. Fisheries Management and Ecology, 7: 167-178.

FRANSSEN, N. R. 2011. Anthropogenic habitat alteration induces rapid morphological divergence in a native stream fish. Evolutionary Applications, 4: 791-804.

GASITH, A. \& V. H. RESH. 1999. Streams in Mediterranean climate regions: abiotic influences and biotic responses to predictable seasonal events. Annual Review of Ecology and Systematics, 30: 5181.

HAMMER, C. 1995. Fatigue and exercise tests with fish. Comparative Biochemistry and Physiology A, 112: 1-20.

HERRERA, M. \& C. FERNANDEZ-DELGADO. 1994. The age, growth and reproduction of Chondrostoma polylepis willkommi in a seasonal stream of the Guadalquivir River basin (southern Spain). Journal of Fish Biology, 44: 11-22.

KOLOK, A. S. 1992. Morphological and physiological correlates with swimming performance in juve- 
nile largemouth bass. American Journal of Physiology, 263: R1042-R1048.

LANGERHANS, R. B. 2008. Predictability of phenotypic differentiation across flow regimes in fishes. Integrative and Comparative Biology, 48: 750-768.

MAS-MARTI, E., E. GARCIA-BERTHOU, S. SABATER, S. TOMANOVA \& I. MUÑOZ. 2010. Comparing fish assemblages and trophic ecology of permanent and intermittent reaches in a Mediterranean stream. Hydrobiologia, 657: 167-180.

MATEUS, C. S., B. R. QUINTELLA \& P. R. ALMEIDA. 2008. The critical swimming speed of Iberian barbel Barbus bocagei in relation to size and sex. Journal of Fish Biology, 73: 1783-1789.

OLIVA-PATERNA, F. J., P. A. MIÑAMO \& M. TORRALVA. 2003. Habitat quality affects the condition of Barbus sclateri in Mediterranean semi-arid streams. Environmental Biology of Fishes, 67: 13-22.

PEAKE, S. J. 2008 Swimming performance and behavior of fish species endemic to Newfoundland and Labrador: a literature review for the purpose of establishing design and water velocity criteria for fishways and culverts. Canadian Manuscript Report of Fisheries and Aquatic Sciences, Canadian Journal of Fisheries and Aquatic Sciences, 2843: $\mathrm{v}, 52$.

PEAKE, S., R. S. MCKINLEY \& D. A. SCRUTON. 1997. Swimming performance of various freshwa- ter Newfoundland salmonids relative to habitat selection and fishway design. Journal of Fish Biology, 51: 710-723.

PLAUT, I. 2001. Critical swimming speed: its ecological relevance. Comparative Biochemistry and Physiology A, 131: 41-50.

ROMÃO, F., B. R. QUINTELLA, T. J. PEREIRA \& P. R. ALMEIDA. 2012. Swimming performance of two Iberian cyprinids: the Tagus nase Pseudochondrostoma polylepis (Steindachner, 1864) and the bordallo Squalius carolitertii (Doadrio, 1988). Journal of Applied Ichthyology, 28: 26-30.

SANZ-RONDA, F. J., J. R. LEGAZPI, F. J. BRAVOCÓRDOBA, S. MAKRAKIS \& T. CASTROSANTOS. 2015. Sprinting performance of two Iberian fish: Luciobarbus bocagei and Pseudochondrostoma duriense in an open channel flume. Ecological Engineering, 83: 61-70.

TUDORACHE, C., P. VIAENEN, R. BLUST \& G. DE BOECK. 2007. Longer flumes increase critical swimming speeds by increasing burst and glide swimming duration in carp (Cyprinus carpio L.). Journal of Fish Biology, 71: 1630-1638.

TUDORACHE, C., P. VIAENEN, R. BLUST, H. VEREECHEN \& G. DE BOECK. 2008. A comparison of swimming capacity and energy use in seven European freshwater fish species. Ecology of Freshwater Fish 17: 284-291. 